\title{
Analysis and comparison of different PV technologies for determining the optimal PV panels- A case study in Mohammedia , Morocco.
}

\author{
A. Elamim ${ }^{1}$, B. Hartiti ${ }^{1 *}$, A.Haibaoui ${ }^{2}$, A. Lfakir ${ }^{3}$ P.Thevenin ${ }^{4}$ \\ ${ }^{I}$ MAC \& PM Laboratory, MEE \&DD Group ,University Hassan ll casablanca FSTM , BP 146 Mohammedia \\ 20650,Morocco \\ "Senior Assoc, ICTP,UNESCO, Trieste, Italy \\ ${ }^{2}$ LIMAT Laboratory, Department of Physics, University Hassan II FSB, Casablanca, Morocco \\ ${ }^{3}$ University Sultan Moulay Slimane FSTB, BP 523 Beni Melall, Morocco \\ ${ }^{4}$ LMOPS Laboratory, Department of Physics University of Lorraine Metz, France
}

\begin{abstract}
This study focuses on the analysis and comparison of three different photovoltaic technologies of silicon module: Amorphous silicon (a-Si), polycrystalline silicon ( $\mathrm{pc}$-Si) and monocrystalline silicon ( $\mathrm{mc}$-si) with $2 \mathrm{KWp}$ for each one of theme, connected to the grid, when they are exposed to the same real sun conditions over a one year period under the meteorological conditions of Mohammedia (Morocco), to determine the optimal PV power system in the region. For this aim, the amount of energy generated by each system, cost analysis, annual incomes, breakeven points, annual CO2 emissions avoided, installation area occupied by the system and total weights of each system are evaluated for each panel type used in the installed system and potential energy to be generated by solar energy in the region was considered. Following energy generation, which lasted one year, it is concluded that ploy-crystalline silicon panels are the most optimal panel for the region because it yields the highest annual incomes and the shortest breakeven point for the investors.
\end{abstract}

Keywords: Optimal PV panels. mono-crystalline. Poly-crystalline. Amorphous. cost analysis. annual incomes.

\section{Introduction}

The shortage of fossil energy sources, the increase of their prices, the environmental problems caused by their consumption such as pollution and global warming, are encouraging the application of renewable energy in several countries around the world. Renewable resources are also ecological and abundant in the planet. Among renewable technologies, solar systems that are the best suited to meet certain energy requirements. [1, 2, 3]. There are different types of solar energy (thermal, PV, thermodynamic) used in agriculture, water treatment, electrification, drying and road signs. [4, 5]

Photovoltaic technology is now in full development in the world, the photovoltaic modules are efficient, sustainable, and eco-friendly, used to convert sunlight into electrical energy, but it still requires performance improvements to achieve a better competitiveness. [6, 7, 8].

The main PV industries are silicon cells $(\mathrm{Si})$ that can be made from crystalline silicon wafers (c-Si) into two distinct categories, mono-crystalline silicon and polycrystalline silicon, with a gap of 1,12 ev, the monocrystalline silicon is more expensive than the polycrystalline but allows higher yields, with almost $24.5 \%$ against $19 \%$ record performance in laboratory cells $[9,10]$. Currently the market is widely covered with commercial modules generally with yields of $12 \%$ to $14 \%$ for polycrystalline and $15 \%$ to $16 \%$ for mono-crystalline. [11]

According to "Loïc GOEMAERE" [11] amorphous silicon, denoted a-Si, has an absorption coefficient much more higher in the visible range than the crystalline silicon, due to the absorption process of the photons more efficient so-called direct. This makes it possible to considering the manufacture of cells using thin layers, of the order of a micron of thickness, which makes it possible to reduce significantly the costs of production. Despite lower modules yields than crystalline silicon modules (from 6 to $7 \%$ ), this sector tends to develop in a context of strong demand, and is positioned after the dies crystalline silicon (4\%). Research has turned to other materials than silicon, they are the CdTe, CIS, CIGS sectors. [11]

General view in perspective of some photovoltaic technologies and classification is illustrated in the figure 1.

In Morocco, solar energy is the most important renewable energy with more than 3000 hours per year of sunshine, with an irradiation about $5 \mathrm{kWh}$ per $\mathrm{m}^{2}$ per day. Morocco possesses a considerable solar radiation. The map right below represents the global solar radiation in Morocco, it has been made by IRESEN in collaboration with mines Paris Tech. The overall radiation does not go down below $1405 \mathrm{kWh}$ per $\mathrm{m}^{2}$ and can reach $2574 \mathrm{kWh}$ per $\mathrm{m}^{2}$. [12] 


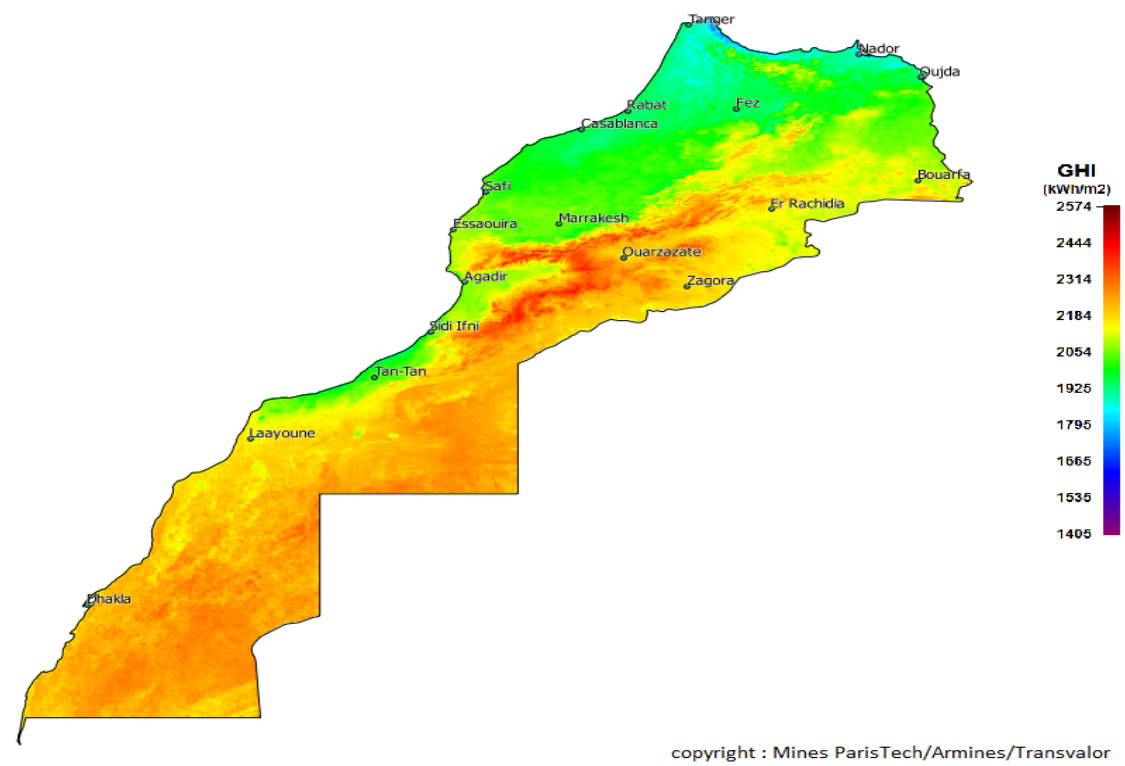

Fig.1.Map of global horizontal solar irradiation in Morocco

The performance of PV modules varies by region, geographical location and climatic conditions, so it is necessary to determine the type of technology or PV panel to be used depending on weather conditions. In this respect, and because no study was done in the Mohammedia city which has significant potential in terms of solar radiation, so it is important to find the optimal PV panel for this city. Therefore, in this work three different types of photovoltaic panels Amorphous, poly-crystalline and mono-crystalline with $2 \mathrm{KWp}$ each one of them were selected and analyzed to determine the optimal type of panel for Mohammedia. These systems were analyzed in terms of annual incomes, the installation area occupied by the system, the total weight of the system, the productivity of each system, the initial investment costs, and the system that avoids more $\mathrm{CO}^{2}$.

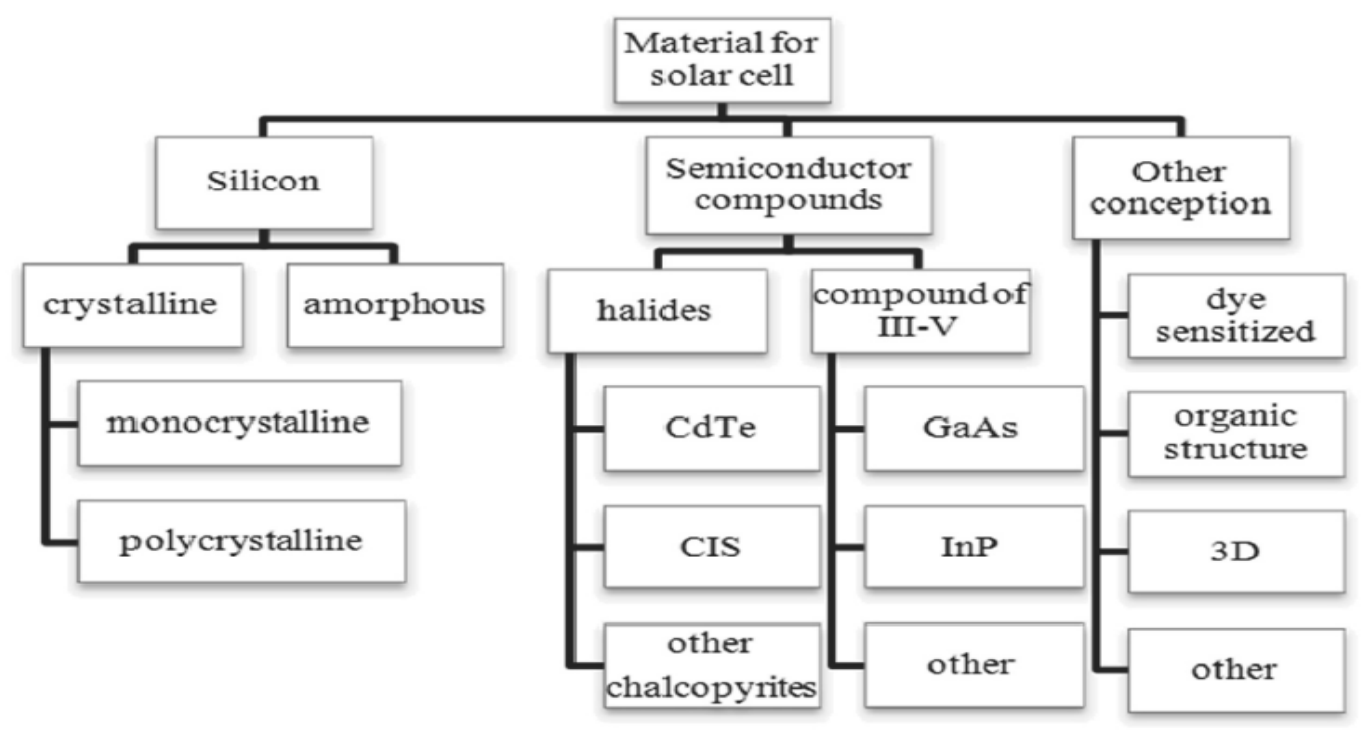

Fig.2.Classification of the silicon PV panels [13]

\section{Site Description And Solar Potential In The Region}

\section{II.1.GEOGRAPHICAL DATA:}

The site is the roof of the research building of the Faculty of Sciences and Techniques in Mohammedia (FSTM) with a latitude of $33^{\circ} 70^{\prime} 58^{\prime}$ 'North and a longitude of $07^{\circ} 35^{\prime} 31^{\prime \prime}$ West. It is located in the city of Mohammedia with a latitude of $33^{\circ} 41^{\prime} 23^{\prime}$ 'North and a longitude of $07^{\circ} 23^{\prime} 23$ " West. It is a town between Rabat and Casablanca in the largest region of Casablanca. It is located on the coast of the Atlantic Ocean, $24 \mathrm{~km}$ north-east of the economic capital of the kingdom, as shown in Fig. 3. The city of Mohammedia has a Mediterranean climate with mild/wet winters and warm/dry summers. [14] 


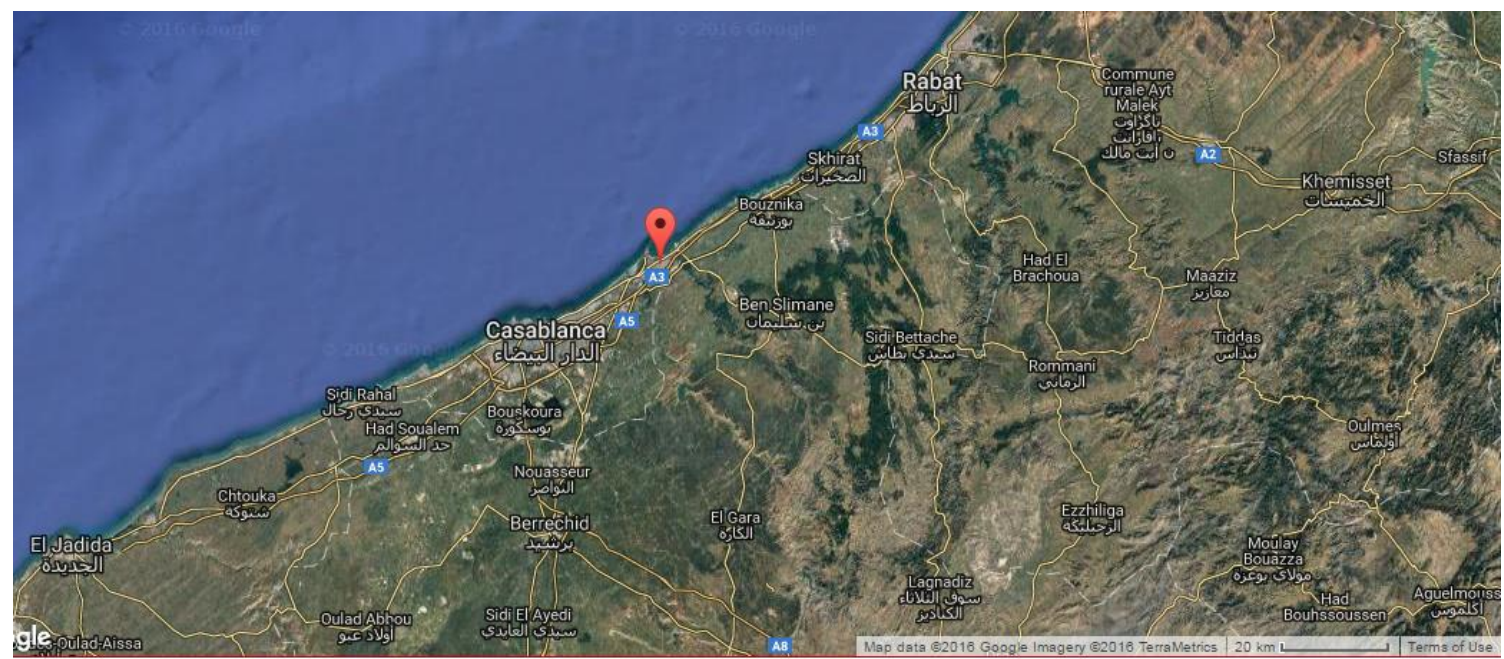

Fig .3 Location of Mohammedia city by Google Earth.

\section{II.2.METEOROLOGICAL DATA:}

These data mainly concern the temperatures and sunshine of the site. The city of Mohammedia largely enjoys sun throughout the year. In summer (May to October), the maximum average temperatures are between 23 and $29{ }^{\circ} \mathrm{C}$, but can occasionally reach $35^{\circ} \mathrm{C}$ and a minimum of 14 to $19^{\circ} \mathrm{C}$.

The duration of sunshine reaches 8 to 10 hours per day. In winter (November to April), the maximum average temperatures are between 20 and $23{ }^{\circ} \mathrm{C}$, with a minimum of 9 to $12{ }^{\circ} \mathrm{C}$ and they can often drop to $2{ }^{\circ} \mathrm{C}$ in the morning. The duration of daily sunlight during the winter is 5 to 6 hours. [15]

The data on these parameters are given In Table 1. [16]

Table.1.Average daily meteorological data in the region

\begin{tabular}{|c|c|c|c|c|c|}
\hline & $\begin{array}{c}\mathbf{G H I} \\
\left(\mathbf{K w h} / \mathbf{m}^{\mathbf{2}}\right)\end{array}$ & $\begin{array}{c}\mathbf{D I F F} \\
\left(\mathbf{K w h} / \mathbf{m}^{\mathbf{2}}\right.\end{array}$ & $\begin{array}{c}\mathbf{D N I} \\
\left(\mathbf{K W h} / \mathbf{m}^{\mathbf{2}}\right)\end{array}$ & $\begin{array}{c}\text { Sunshine duration } \\
\mathbf{( h )}\end{array}$ & $\begin{array}{c}\text { Wind speed } \\
(\mathbf{m} / \mathbf{s})\end{array}$ \\
\hline January & 95 & 34 & 136 & 6 & 3 \\
\hline February & 106 & 41 & 126 & 6,8 & 3,2 \\
\hline March & 158 & 54 & 174 & 7,5 & 3,6 \\
\hline April & 189 & 63 & 188 & 8,4 & 3,8 \\
\hline May & 218 & 80 & 200 & 9,4 & 3,9 \\
\hline June & 222 & 80 & 198 & 9,5 & 3,7 \\
\hline July & 227 & 80 & 207 & 10 & 3,8 \\
\hline August & 209 & 70 & 204 & 9,6 & 3,6 \\
\hline September & 170 & 59 & 173 & 8,6 & 3,4 \\
\hline October & 133 & 50 & 148 & 7,8 & 3,4 \\
\hline November & 100 & 35 & 140 & 6,2 & 3 \\
\hline December & 86 & 30 & 135 & 5,9 & 3,3 \\
\hline year & 1910 & 677 & 2029 & 7,9 & 3,5 \\
\hline
\end{tabular}

GHI : global horizontal irradiance.

DIFF:horizontal diffuse irradiation.

DNI:direct normal irradiance .

\section{Description of The PV System:}

\section{III.1.SYSTEM DESCRIPTION}

The PV plant consists of three different technology modules that are mounted on the roof of the research FSTM block on a galvanized steel structure (see Fig. 4), with South orientation and an inclination of $30^{\circ}$. The properties of the boards used are listed in the Table 2 . 


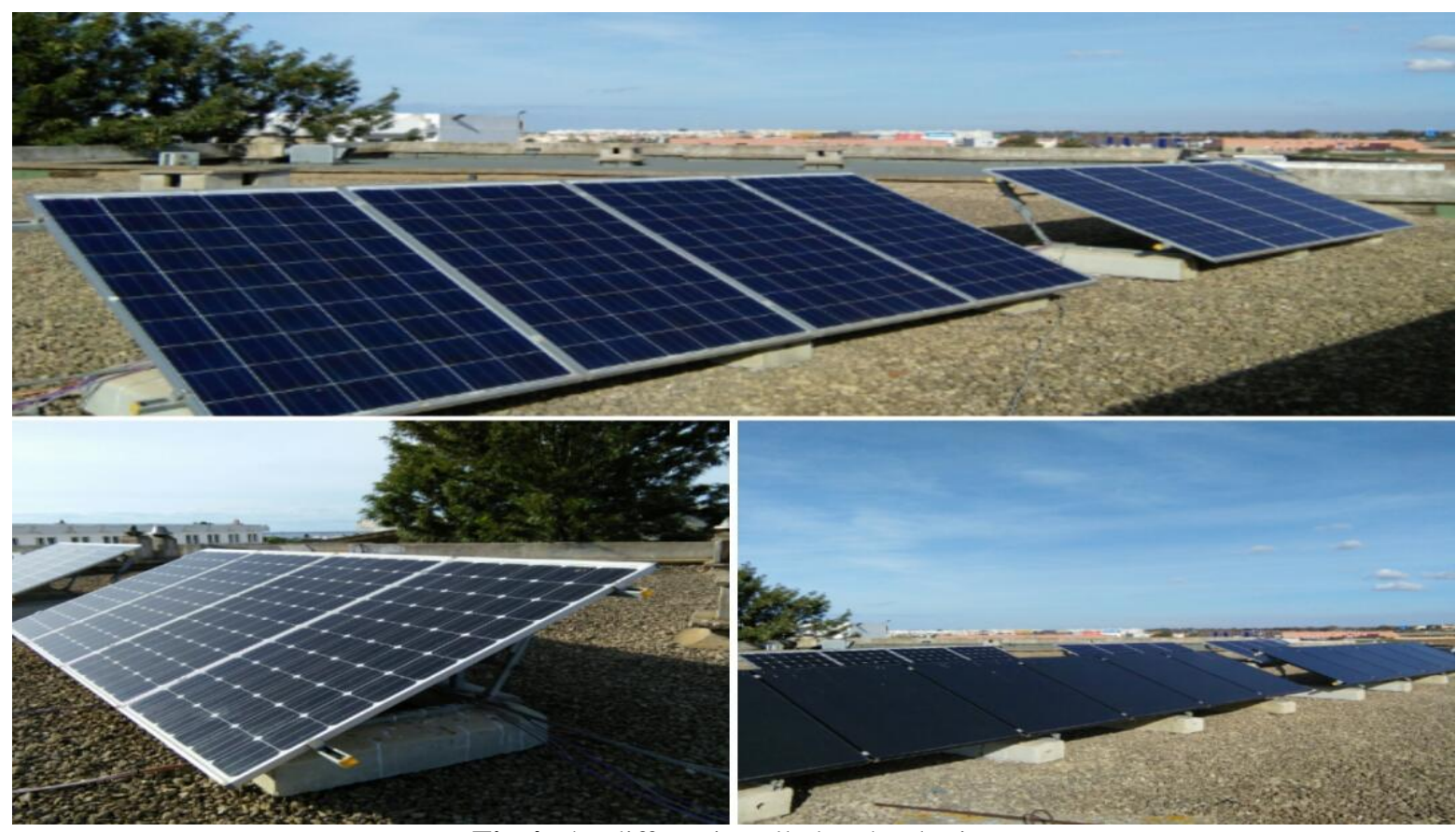

Fig.4.The diffrent installed technologies

Table.2.Main characteristics of the different modules.

\begin{tabular}{|c|c|c|c|}
\hline Trademark & NEXPOWER & \multicolumn{2}{|c|}{ SOLARWORLD } \\
\hline Model & $\begin{array}{l}\text { XTREM }^{+}(\mathrm{NT}-155 \\
\text { AF) }\end{array}$ & $\begin{array}{l}\text { SUNMODULE plus SW } 255 \\
\text { poly }\end{array}$ & $\begin{array}{c}\text { SUNMODULE } \\
\text { Plus SW } 255 \text { mono }\end{array}$ \\
\hline Solar cell & Amorphous & Poly-crystalline & Mono-crystalline \\
\hline Maximum power at STC $\left(\mathbf{P}_{\max }\right)$ & $155 \mathrm{Wp}$ & $255 \mathrm{Wp}$ & $255 \mathrm{Wp}$ \\
\hline Optimum operating voltage $\left(V_{\mathrm{mp}}\right)$ & $65.9 \mathrm{~V}$ & $30.9 \mathrm{~V}$ & $31.4 \mathrm{~V}$ \\
\hline Optimum operating current $\left(\mathbf{I}_{\mathrm{mp}}\right)$ & $2.43 \mathrm{~A}$ & $8.32 \mathrm{~A}$ & $8.15 \mathrm{~A}$ \\
\hline Open circuit voltage $\left(\mathbf{V}_{o c}\right)$ & $85.5 \mathrm{~V}$ & $38 \mathrm{~V}$ & $37.8 \mathrm{~V}$ \\
\hline Short circuit current $\left(\mathbf{I}_{\text {sc }}\right)$ & $2.57 \mathrm{~A}$ & $8.88 \mathrm{~A}$ & $8.66 \mathrm{~A}$ \\
\hline Module efficiency & $9,87 \%$ & \multicolumn{2}{|l|}{$15.2 \%$. } \\
\hline Length & $1412 \mathrm{~mm}$ & \multicolumn{2}{|c|}{$1675 \mathrm{~mm}$} \\
\hline Width & $1112 \mathrm{~mm}$ & \multirow{2}{*}{\multicolumn{2}{|c|}{$\frac{1001 \mathrm{~mm}}{21.2 \mathrm{~kg}}$}} \\
\hline Weight & $19.5 \mathrm{~kg}$ & & \\
\hline
\end{tabular}

\section{III.2.Specifications of selected inverter:}

The Inverter model used in each plant is SB2000HF and its specifications are listed in Table 3.

The output characteristics of amorphous, mono-crystalline and poly-crystalline are shown in Figs. 5-7, [17].

Table.3.Properties of inverters used in each PV power plant.

\begin{tabular}{|c|c|c|c|c|c|}
\hline \multicolumn{3}{|c|}{ Inverter type: SB 2000HF } & & AC nominal power & $2000 \mathrm{~W}$ \\
\hline \multirow[t]{8}{*}{ Input (DC) } & $\begin{array}{l}\text { Max. recommended } \\
\text { PV power }\end{array}$ & $2100 \mathrm{~W}$ & \multirow[t]{8}{*}{ Output (AC) } & $\begin{array}{l}\text { Max. AC apparent } \\
\text { power }\end{array}$ & $2000 \mathrm{VA}$ \\
\hline & Max. DC voltage & $700 \mathrm{~V}$ & & Nominal AC voltage & $220 \mathrm{~V} / 230 \mathrm{~V} / 240 \mathrm{~V}$ \\
\hline & DC nominal voltage & $530 \mathrm{~V}$ & & AC voltage range & $180 \mathrm{~V}-280 \mathrm{~V}$ \\
\hline & MPP voltage range & $175 \mathrm{~V}-560 \mathrm{~V}$ & & $\begin{array}{l}\text { AC grid frequency; } \\
\text { range }\end{array}$ & $50 / 60 \mathrm{~Hz}$ \\
\hline & $\begin{array}{l}\text { Min. DC voltage/start } \\
\text { voltage }\end{array}$ & $220 \mathrm{~V}$ & & Max. output current & $8.3 \mathrm{~A}$ \\
\hline & $\begin{array}{l}\text { Max. input } \\
\text { current/per string }\end{array}$ & $12.0 \mathrm{~A}$ & & Power factor $(\cos \varphi)$ & 1 \\
\hline & Max. efficiency & $96.6 \%$ & & Harmonics & $\leq 3 \%$ \\
\hline & & & & Packing weight & $17 \mathrm{Kg}$ \\
\hline
\end{tabular}


Fig. 5. Output characteristics of the used monocrystalline-Si : I-V characteristics and P-V characteristics. Module PV: SolarWorld, Sunmodule SW 255 mono Module PV: SolarWorld, Sunmodule SW 255 mono
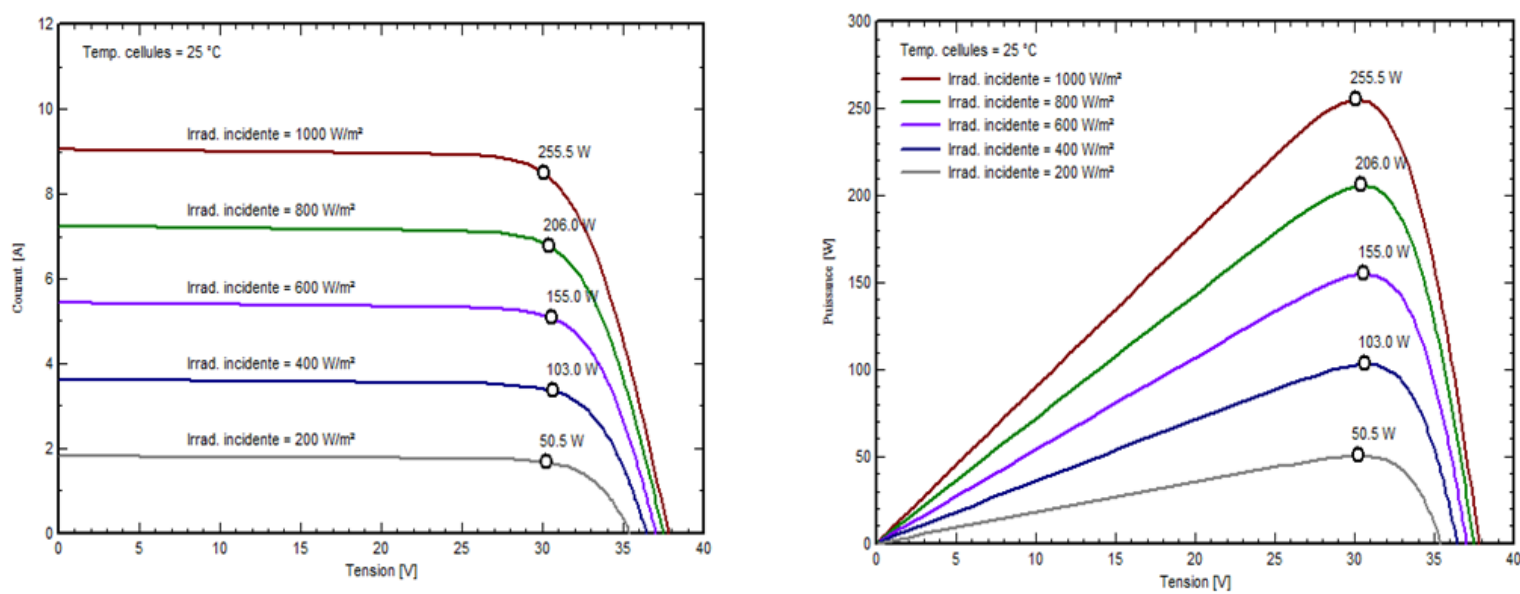

Fig. 6. Output characteristics of the used amorphous-Si : I-V characteristics and P-V characteristics. Module PV: NexPower, NT-155AF
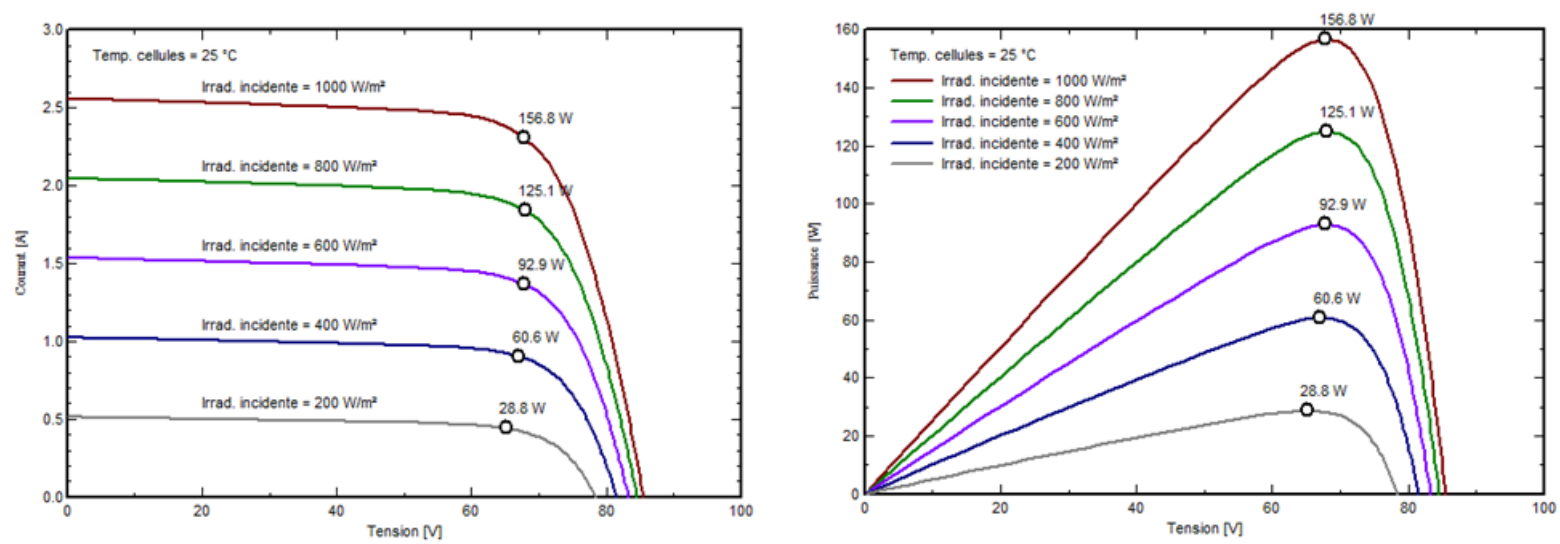

Fig. 7. Output characteristics of the used polycristalline-Si : I-V characteristics and P-V characteristics.

Module PV: SolarWorld, Sunmodule Plus SW 255 poly

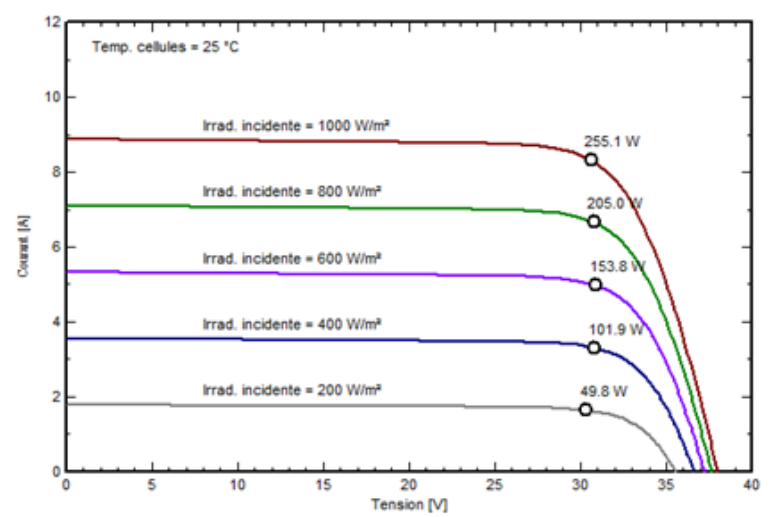

Module PV: SolarWorld, Sunmodule Plus SW 255 poly

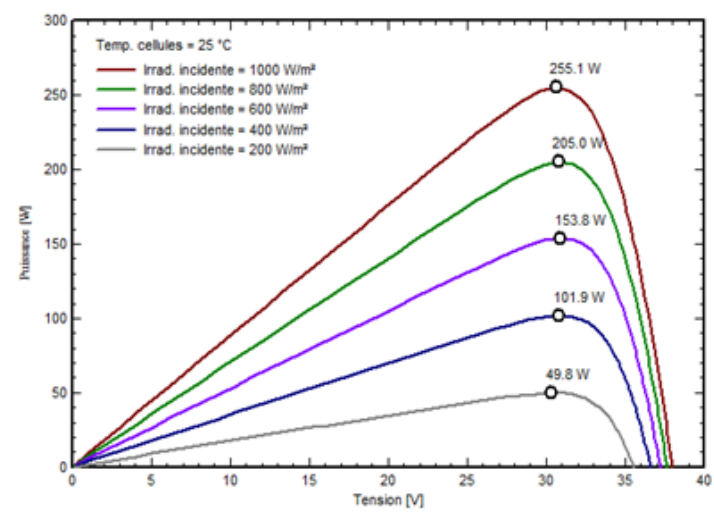

\section{IV.1.Comparison and analysis of energy:}

\section{Results And Discussion}

In order to choose the appropriate technology for the city of Mohammedia we proceeded to make a comparison of energy produced by each technology, for that the energy generated by each PV system, was registered for a whole year from $1^{\text {st }}$ January 2015 until December 2015 as shown in FIG.8.

The first installation constructed by mono-crystalline panels generated $3432.551 \mathrm{KWh}$, the second installation constructed by poly-crystalline panels generated $3463.58 \mathrm{KWh}$ and the amorphous technology generated $3175.964 \mathrm{KWh}$, the total energy produced by the three technologies is around $10072 \mathrm{KWh}$ per year. 


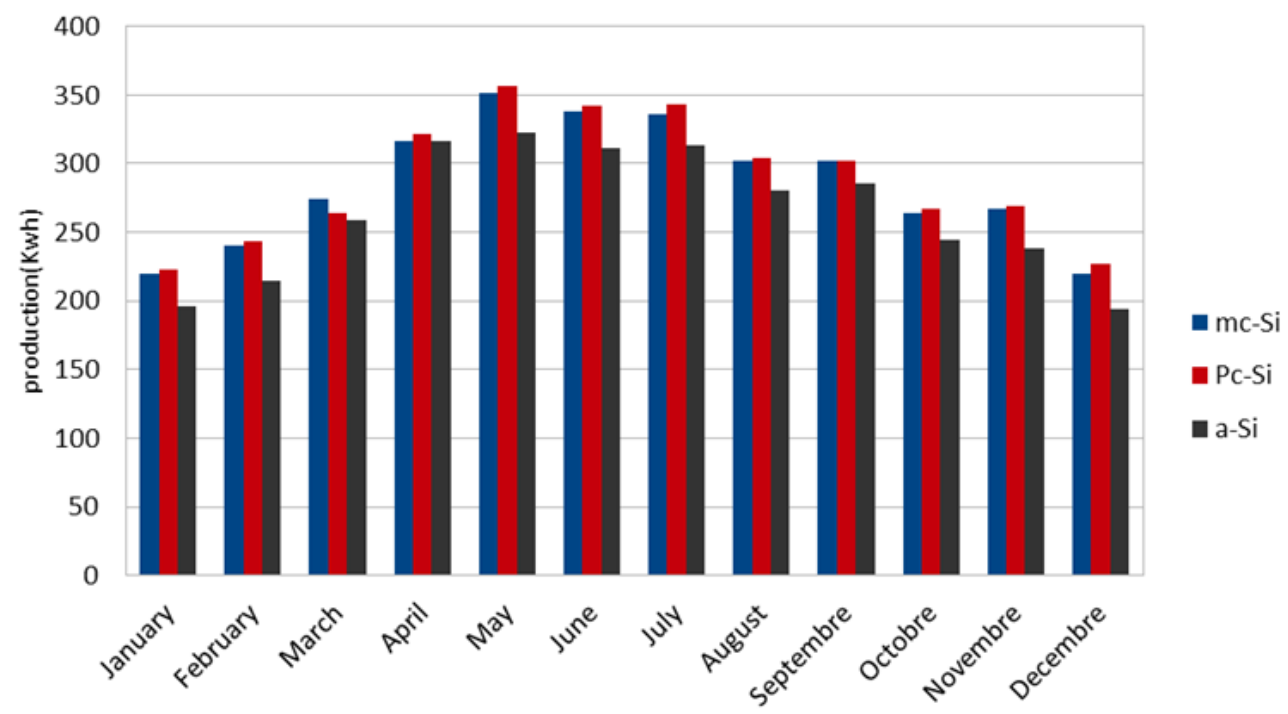

Fig.8. Harvested energy profile from the three-plant all year round.

On figure 8, we can observe the output gap between the different PV modules technologies used in the installation. A low irradiation and low temperature (autumn, winter) modules (poly-crystalline) appear most receptive, whereas at high irradiation and high temperature (spring, summer) the mono-crystalline and polycrystalline modules are virtually identical while the amorphous technology appears weaker. However, we can conclude that the perceived difference between the technologies of the installation implies that polycrystalline modules have the best performance in terms of the city of Mohammedia.

\section{IV.2.Analysis and comparison of costs:}

Because of their high yields, modules in mono-crystalline silicon and polycrystalline, are the most important modules in the PV market [18].

To identify and decide the most optimal panels it is necessary to do a cost analysis of the various systems installed. To this aim, taking the whole system installation into account, the cost analysis of each system together with annual incomes and their break-even points is given in the Table 4.

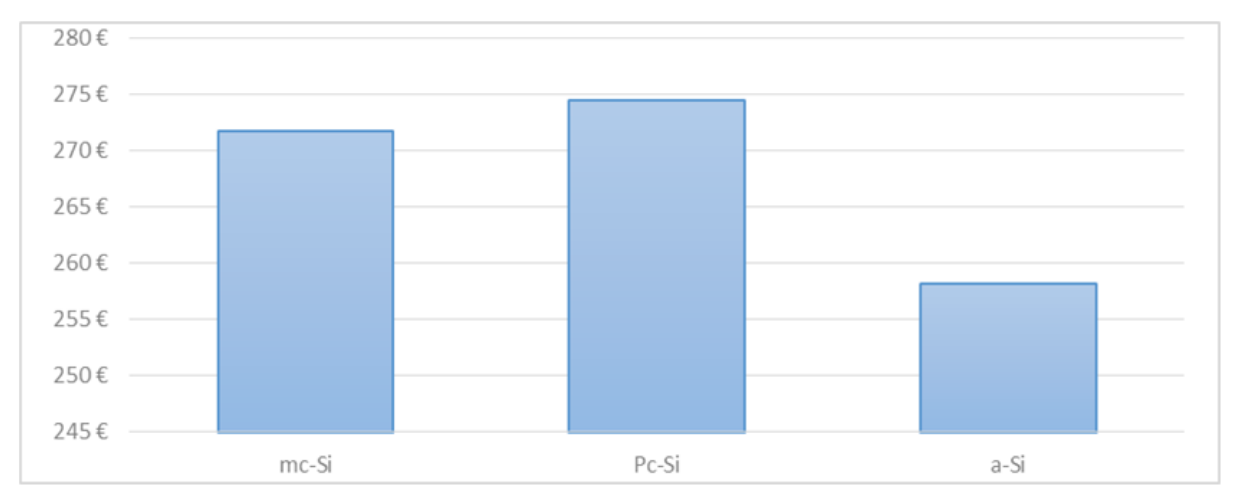

Fig.9.Total yearly incomes for all three-system

Table.4. Cost analysis for each system installed and their breakeven points.

\begin{tabular}{|c|c|c|c|c|c|c|c|c|c|}
\hline Components & \multicolumn{3}{|c|}{ Amorphous } & \multicolumn{3}{|c|}{ Poly-crystalline } & \multicolumn{3}{|c|}{ Mono-crystalline } \\
\hline PV modules & $182 €$ & 12 & $2184 €$ & $255 €$ & 8 & $2040 €$ & $265 €$ & 8 & $2120 €$ \\
\hline inverter & $1318 €$ & 1 & 1318 & $1318 €$ & 1 & $1318 €$ & 1318 & 1 & $1318 €$ \\
\hline Taxes and support equipements & \multicolumn{3}{|l|}{$565 €$} & \multicolumn{3}{|l|}{$376 €$} & \multicolumn{3}{|l|}{$376 €$} \\
\hline Total & \multicolumn{3}{|l|}{$4067 €$} & \multicolumn{3}{|l|}{$3734 €$} & \multicolumn{3}{|c|}{$3814 €$} \\
\hline Net initial investment cost & \multicolumn{3}{|l|}{$4067 €$} & \multicolumn{3}{|l|}{$3734 €$} & \multicolumn{3}{|c|}{$3814 €$} \\
\hline $\mathrm{PV} \operatorname{costs}(€ / \mathrm{W} h)$ & \multicolumn{3}{|l|}{1.174} & \multicolumn{3}{|l|}{1.00} & \multicolumn{3}{|c|}{1.04} \\
\hline System costs $(€ / \mathrm{W} h)$ & \multicolumn{3}{|l|}{2.03} & \multicolumn{3}{|l|}{1.867} & \multicolumn{3}{|l|}{1.907} \\
\hline Production [KW h] per year & \multicolumn{3}{|l|}{3175} & \multicolumn{3}{|l|}{3376} & \multicolumn{3}{|c|}{3342} \\
\hline Fixed feed in tariff per $\mathrm{kW} \mathrm{h}$ & \multicolumn{3}{|l|}{$0.0813 €$} & \multicolumn{3}{|l|}{$0.0813 €$} & \multicolumn{3}{|c|}{$0.0813 €$} \\
\hline Total yearly income & \multicolumn{3}{|c|}{$252.2 €$} & \multicolumn{3}{|c|}{$274.503 €$} & \multicolumn{3}{|c|}{$271.753 €$} \\
\hline Breakeven points & \multicolumn{3}{|c|}{16.12 years } & \multicolumn{3}{|c|}{13.6 years } & \multicolumn{3}{|c|}{14.03 years } \\
\hline
\end{tabular}


Considering the investment costs, we notice that the polycrystalline system is the least expensive of the three systems.

From the Figure 9 and table 4 we see that the systems consisting of polycrystalline type modules is more productive than the two other systems in terms of annual incomes.

IV.3.Analysis and comparison of weight and areas occupied by the systems:

After comparing the generated electricity and the costs of the systems, we can notice that the area occupied by the systems and their weight are also important criteria to validate the decision.

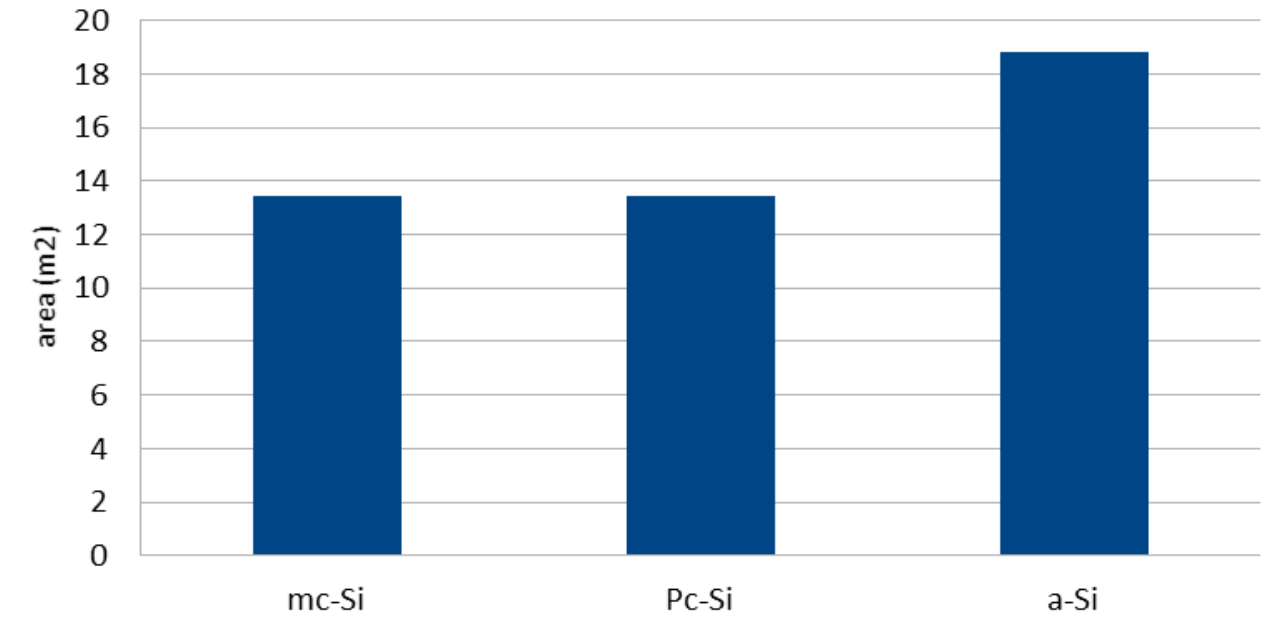

Fig.10. Comparison of the areas occupied by each power system.

From the curves 10 and 11 we note that the mono-crystalline and polycrystalline systems are the least heavy systems, which occupies less area.

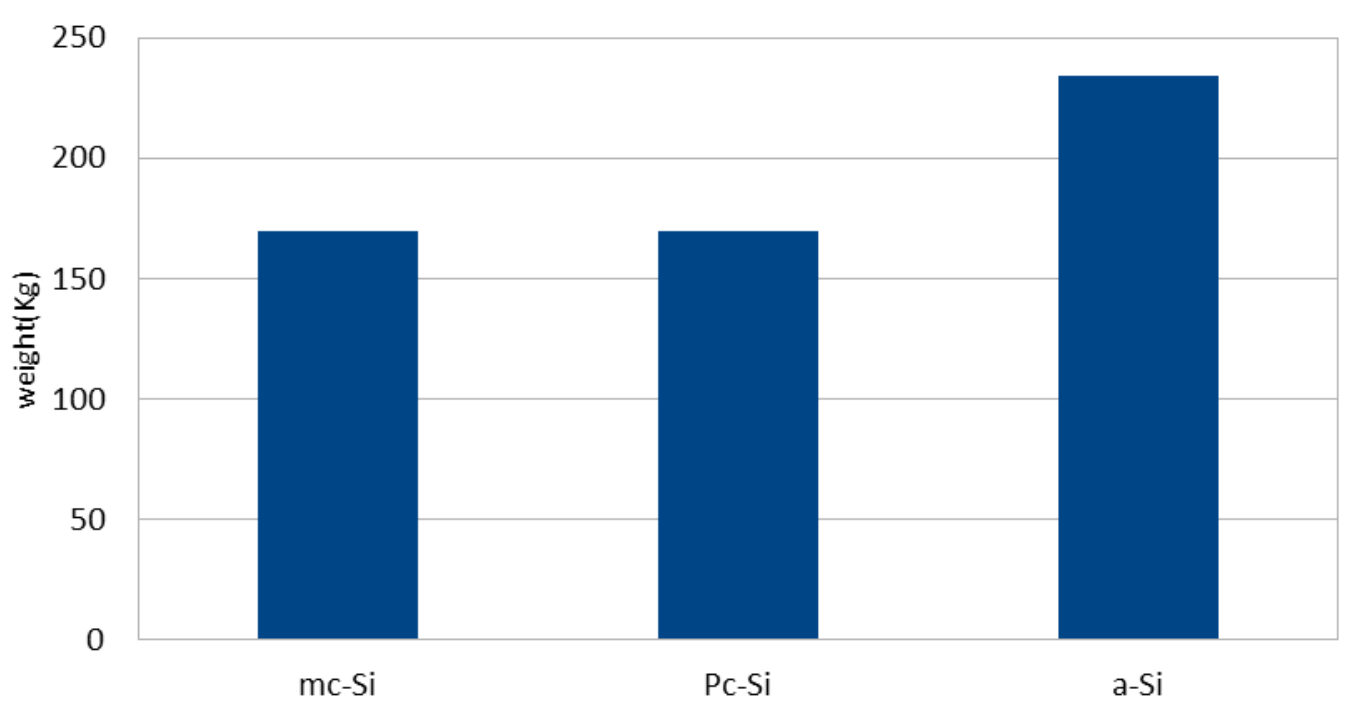

Fig.11. Comparison of the weights for the installed systems.

\section{IV.4.Analysis and comparison of $\mathrm{CO}_{2}$ emissions avoided:}

$\mathrm{CO}_{2}$ and water vapor are the main gas responsible for the greenhouse effect, but using renewable energy and specifically PV systems, we can reduce these emissions.

Therefore, the avoided $\mathrm{CO}_{2}$ emissions for solar PV systems is determined by assuming that each $\mathrm{kWh}$ generated by the solar energy system replaces each KWh produced by conventional energy systems. Avoided $\mathrm{CO}_{2}\left(\mathrm{EM}_{\mathrm{AV}}\right.$ in tones) can be expressed by the equation. [19] 


$$
E M A V=\frac{\mathrm{EC} \times \mathrm{FC}}{1000}
$$

$E_{C}$ where: is the energy generated by conventional systems $(\mathrm{KWh})$ during a reference period and the $\mathrm{F}_{\mathrm{C}}$ is the carbon mitigation factor.

$\mathrm{F}_{\mathrm{C}}$ : is calculated by subtracting the life cycle of $\mathrm{PV}$ transmission system (estimated at $53 \mathrm{~g} \mathrm{CO}^{2} \mathrm{eq} / \mathrm{KWh}$ for $\mathrm{pc}-$ $\mathrm{Si}, 61 \mathrm{~g} \mathrm{CO}^{2} \mathrm{eq} / \mathrm{KWh}$ for mc-Si and $47 \mathrm{~g} \mathrm{CO}^{2} \mathrm{eq} / \mathrm{KWh}$

For a-Si [20].

(For Morocco is estimated to $746 \mathrm{~g} \mathrm{CO} / \mathrm{KWh}$ )[21].

Table.5.Comparision of the annual avoided $\mathrm{CO} 2$ by each power system.

\begin{tabular}{|l|l|}
\hline Installation type & Annual avoided $\mathrm{CO}_{2}$ (tonnes) \\
\hline $\mathrm{mc}-\mathrm{Si}$ & 2.56 \\
\hline $\mathrm{pc}-\mathrm{Si}$ & 2.58 \\
\hline $\mathrm{a}-\mathrm{Si}$ & 2.37 \\
\hline
\end{tabular}

\section{Conclusion}

The present paper investigates photovoltaic panel comparison between amorphous, poly-crystalline and mono-crystalline of $2 \mathrm{KWp}$ grid-connected $\mathrm{PV}$ systems installed on the roof of the research building of the Faculty of Sciences and Techniques in Mohammedia (Morocco),

in order to determine the most optimal PV systems of this city. Annual energy generated, annual income, breakeven points, the occupied surface and the weight of each system, were evaluated and compared for the three installed technologies. The main results of this study are as following:

- The system consisting of poly-crystalline type PV panels is more suitable for the region and more productive than the two other systems.

- The cost analysis shows that, PV cost of electricity, annual incomes and payback period for monocrystalline installation are, respectively, $1.04 € / \mathrm{Wh}, 271 €$ and 14.03 years, for poly-crystalline are, respectively, $1.00 € / \mathrm{Wh}, 274 €$ and 13.6 years and are $1.174 € / \mathrm{Wh}, 252 €$ and 16.12 years for Amorphous installation.

- It is also found that the installed PV systems have the potential of reducing approximately 7.58 tons of $\mathrm{CO} 2$ emission: 2.56 tons by mono-crystalline, 2.58 tons by poly-crystalline and 2.37 tons by amorphous,

We conclude that the system consisting of poly- crystalline is the most optimal type for the city of Mohammedia located in morocco.

\section{Acknowledgements}

We thank IRESN institute (Morocco) for their financial support to Propre.ma project.

\section{References}

[1]. Schroeder M. Utilizing the clean development mechanism for the deployment of renewable energies in China. Appl Energy 2009;86(2):237-42.

[2]. Hasanuzzaman M, Al-Amin AQ, Khanam S, Hosenuzzaman M. Photovoltaic power generation and its economic and environmental future in Bangladesh. J Renew Sustain Energy 2015;7(1):013108.

[3]. Jacovides CP, Theophilou K, Tymvios FS, Pashiardes S. Wind statistics for coastal station in Cyprus. Theor Appl Climatol 2002;72:259-63.

[4]. Chen AA,ForrestW,ChinPN,McLeanP,Grey C.Solar radiation in Jamaica.Sol Energy 1994;53(5):455-60.

[5]. Jain PC.Amodel for diffuse and global irradiationon horizontal surfaces.Sol Energy 1990;45:301-8.

[6]. Hosenuzzaman M, Rahim NA, Selvaraj J, Hasanuzzaman M, Malek ABMA, Nahar A. Global prospects, progress, policies, and environmental impact of solar photovoltaic power generation. Renew Sustain Energy Rev 2015;41:284-97.

[7]. Ahmed F, Al Amin AQ, Hasanuzzaman M, Saidur R. Alternative energy resources in Bangladesh and future prospect. Renew Sustain Energy Rev 2013;25:698-707.

[8]. L.A. Dobrzański, A. Drygała, M. Giedroć, M. Macek, Monocrystalline silicon solar cells applied in photovoltaic system, Journal of Achievements in Materials and Manufacturing Engineering 53/1 (2012) 7-13.

[9]. J.Zhao, A.Wang, P.Campbell, M.A.Green. A 19,8\% efficient honeycomb multicrystalline silicon solar cell with improved light trapping. IEEE p 1978, 1999.

[10]. solar cells. IEEE, Conférence Record of the Twenty Fourth, 1994

[11]. Loïc GOEMAERE. Comparaison de la production de trois technologies différentes depanneaux solaires en fonctionnement réel avec suivi du soleil et integration de batterie lithium innovantes adaptées au stockage des énergies, 2011.

[12]. http://www.siem.ma/potentiel-maroc

[13]. R. Ciach, J. Nelazny, Photovoltaic material and technology,Foundation of development in material science, Cracow, 2005 (in Polish).

[14]. http://www.photovoltaique-energie.fr/pvgis-logiciel-en-ligne-de-simulation.html

[15]. http://www.undergrouand.com

[16]. http://METEONORM.com 
[17]. http://www.pvsyst.com/en/

[18]. Vats K, Tiwari GN. Energy and exergy analysis of a building integrated semitransparent photovoltaic thermal (BISPVT) system. Appl Energy 2012;96:409-16.

[19]. A.Allouhi, R.Saadani, T.Kousksou, R.Saidur, A.Jamil,M.Rahmoune, Grid-connected PV system installed on institutional buildings:Technology comparison, energy analysis and economic performance, Energy and Buildings http://dx.doi.org/10.1016/j.enbuild.2016.08.054

[20]. Peng, J., Lu, L., \& Yang, H. (2013). Review on life cycle assessment of energy payback and greenhouse gas emission of solar photovoltaic systems. Renewable and Sustainable Energy Reviews, 19, 255-274.

[21]. Allouhi, A., Kousksou, T., Jamil, A., El Rhafiki, T., Mourad, Y., \& Zeraouli, Y. (2015). Economic and environmental assessment of solar air-conditioning systems in Morocco. Renewable and Sustainable Energy Reviews, 50, 770-781. 